\title{
Sistem Informasi dan Monitoring Tugas Akhir Mahasiswa di Program Studi Teknik Sipil Fakultas Teknik Universitas Tanjungpura
}

\author{
Felik $^{\# 1}$, Heri Priyanto ${ }^{\# 2}$, Hafiz Muhardi ${ }^{\# 3}$ \\ ${ }^{a}$ Program Studi Teknik Informatika, Universitas Tanjungpura \\ Jl. Prof. Dr. H. Nawawi, Pontianak, Kalimantan Barat 78115 \\ ${ }^{1}$ felikestudent.untan.ac.id \\ ${ }^{2}$ heripriyantodinformatika.untan.ac.id \\ ${ }^{3}$ hafizmeinformatika.untan.ac.id
}

\begin{abstract}
Abstrak
Skripsi merupakan satu mata kuliah yang harus diambil oleh mahasiswa di akhir masa studi. Mata kuliah ini berbentuk proyek mandiri yang dilakukan oleh mahasiswa dibawah bimbingan dua dosen pembimbing. Proyek mandiri yang dimaksud dapat berupa laporan yang ditulis sesuai dengan pedoman penulisan tugas akhir. Di program studi Teknik Sipil Universitas Tanjungpura ada beberapa syarat yang harus dipenuhi oleh mahasiswa untuk mengambil mata kuliah tugas akhir yaitu prasyarat nilai dan telah lulus mata kuliah tugas dan praktikum. Proses pengusulan Tugas Akhir tersebut harus diperiksa oleh akademik program studi Teknik Sipil untuk melakukan proses verifikasi pengusulan yang dilakukan oleh mahasiswa. Terdapat beberapa tahapan yang harus dilakukan oleh petugas akademik untuk melakukan verifikasi persyaratan mahasiswa yang akan mengajukan usulan tugas akhir yaitu verifikasi nilai mahasiswa dan verifikasi mata kuliah tugas dan praktikum yang telah diambil oleh mahasiswa. Dibutuhkan dua tahapan secara manual dalam proses tersebut dan berkas-berkas yang menumpuk menjadi permasalahan dalam proses validasi Tugas akhir mahasiswa. Oleh karena itu perlu dilakukan pembuatan sistem informasi yang dapat melakukan proses validasi prasyarat tugas akhir mahasiswa dan memonitor proses tugas akhir tersebut. Penelitian ini dilakukan menggunakan metode waterfall. Sistem informasi yang dibuat akan dilakukan pengujian dengan menggunakan metode pengujian Black-box dan UAT (User Acceptance Test). Proses dalam sistem terdiri dari manajemen data usulan tugas akhir, KST (Kartu Selesai Tugas) dan KSP (Kartu Selesai Praktikum), laporan bimbingan, manajemen berita acara, manajemen mata kuliah, dan manajemen kelompok keahlian. Hasil pengujian dengan metode blackbox menunjukkan sistem informasi berjalan dengan baik. Hasil yang didapat dari pengujian aplikasi menggunakan skala pengukuran Likert mendapatkan skor 1420 dengan nilai cukup positif yang berarti aplikasi dinilai berhasil dan berfungsi sebagaimana mestinya.
\end{abstract}

Kata kunci: Sistem Informasi, Waterfall, Tugas Akhir

\section{Students Final Project Information and Monitoring System in Civil Engineering Faculty of Engineering University of Tanjungpura}

\begin{abstract}
Final Project (TA) is a course that must be taken by students at the end of the study period. This course is in the form of an independent project carried out by students under the guidance of two supervisors. The independent project in question can be a report written in accordance with the guidelines for writing a final assignment. In the Civil Engineering study program, Tanjungpura University, there are several requirements that must be met by students to take final project courses, namely prerequisites for grades and having passed assignments and practicum courses. The final project proposal process must be examined by the academic Civil Engineering study program to carry out the proposal verification process carried out by students. There are several steps that must be taken by academic officers to verify the requirements of students who will submit final project proposals, namely verification of student grades and verification of assignments and practicum courses that have been taken by students. It takes two steps manually in the process and the piling up files become a problem in the validation process of a student's final project. Therefore, it is necessary to make an information system that can validate the prerequisite for student final assignments and monitor the process of the final project. This research was
\end{abstract}


conducted using the waterfall method. The information system created will be tested using the black-box and UAT (User Acceptance Test) testing method. The process in the system consists of final project proposal data management, KST (Completed Task Cards) and KSP (Completed Practicum Cards), guidance reports, management of minutes, course management, and expertise group management. The test results with the black-box method show the information system is running well. The results obtained from testing the application using a Likert measurement scale get a score of 1420 with a positive enough value, which means that the application is considered successful and functions as it should.

Keywords: Information System, Watetfall, Final Project

\section{Pendahuluan}

Tugas akhir merupakan karya ilmiah yang disusun oleh mahasiswa sebagai salah satu syarat untuk meraih gelar akademik dalam studinya. Tugas akhir disusun melalui penelitian sesuai dengan bidang ilmu masing-masing. Penelitian yang dimaksud dapat berupa penelitian kepustakaan, penelitian laboratorium, penelitian klinis, maupun penelitian lapangan. Hal ini bertujuan agar mahasiswa memperoleh pengalaman dalam hal menggali kembali apa yang telah dipelajari, mencari dan mengumpulkan pengetahuan, menganalisanya dengan bantuan dosen pembimbing, dan menyajikannya dalam bentuk tulisan [1].

Di Prodi Teknik Sipil Fakultas Teknik Universitas Tanjungpura Pontianak untuk mengambil mata kuliah Tugas Akhir ada beberapa syarat yang harus dipenuhi oleh mahasiswa, syarat-syarat tersebut adalah telah menempuh minimal 120 SKS, jumlah SKS nilai D maksimal 12 SKS, jumlah SKS nilai E maksimal 6 SKS, dan telah lulus mata kuliah Tugas dan praktiktum dengan melampirkan bukti Kartu Selesai Praktiktum (KSP) dan Kartu Selesai Tugas (KST).

Proses pengusulan Tugas Akhir tersebut harus diperiksa oleh akademik program studi Teknik Sipil untuk melakukan proses verifikasi pengusulan yang dilakukan oleh mahasiswa. Terdapat beberapa tahapan yang harus dilakukan oleh petugas akademik untuk melakukan verifikasi persyaratan mahasiswa yang akan mengajukan usulan tugas akhir yaitu verifikasi nilai mahasiswa dan verifikasi mata kuliah tugas dan praktikum yang telah diambil oleh mahasiswa. Dibutuhkan dua tahapan secara manual dalam proses tersebut dan berkas-berkas yang menumpuk menjadi permasalahan dalam proses validasi Tugas akhir mahasiswa.

Sistem Informasi adalah suatu kegiatan dari prosedurprosedur yang diorganisasikan, bilamana dieksekusi akan menyediakan informasi untuk mendukung pengambilan keputusan dan pengendalian di dalam organisasi [2]. Sistem informasi di sebut juga suatu sistem buatan manusia yang secara umum terdiri atas sekumpulan komponen berbasis komputer dan manual yang dibuat untuk menghimpun, menyimpan dan mengelola data serta menyediakan informasi keluaran kepada pemakai [3].

Dalam membangun sistem informasi tugas akhir di program studi Teknik Sipil Fakultas Teknik Universitas Tanjungpura diperlukan web service untuk melakukan validasi aktivitas login mahasiswa dari database SIAKAD. web service merupakan suatu sistem yang menyediakan pelayanan yang dibutuhkan oleh klien. Klien dari web service tidak hanya berupa aplikasi web, tetapi juga bisa sebuah aplikasi enterprise. Jadi web service tidak sama dengan web server, bahkan sebuah aplikasi web pada web server dapat menjadi klien dari web service. Pelayanan yang diberikan web service bisa berupa XML yang berisi data yang dibutuhkan klien. Web service tidak menampilkan sebuah halamam web, tapi hanya memberikan palayanan permintaan klien yang memiliki izin akses terhadap pelayanan yang diminta [4].

Berdasarkan masalah yang telah diuraikan diatas maka akan dibangun sistem informasi untuk mendukung monitoring Tugas Akhir mahasiswa dari proses pengusulan sampai upload jurnal, serta membantu proses validasi prasyarat tugas akhir oleh operator.

\section{Metodologi Penelitian}

Data penelitian yang digunakan adalah data login mahasiswa dan data nilai mahasiswa via web service SIAKAD. Data login mahasiswa berupa NIM dan password digunakan untuk melakukan proses login ke dalam sistem informasi. Data nilai mahasiswa yang akan digunakan adalah, IPK mahasiswa dan rekap nilai yang sudah diambil oleh mahasiswa. Data IPK mahasiswa diambil dari service profil mahasiswa dan data rekap nilai diambil dari service transkrip yang disediakan oleh web service SIAKAD.

Adapun alat yang digunakan untuk menggambarkan aliran data dalam sistem adalah Data Flow Diagram (DFD). DFD adalah suatu model logika data atau proses yang dibuat untuk menggambarkan darimana asal data dan kemana tujuan data yang keluar dari sistem, dimana data disimpan, proses apa yang menghasilkan data tersebut dan interaksi antara data yang tersimpan dan proses yang dikenakan pada data tersebut [5].

Entity Relationship Diagram (ERD) digunakan untuk menjelaskan hubungan antar data dalam basis data berdasarkan objek-objek dasar data yang memiliki antar relasi. ERD adalah suatu model jaringan yang menggunakan susunan data yang disimpan dalam sistem secara abstrak [6]. ERD menggunakan sejumlah notasi dan simbol untuk menggambarkan struktur dan hubungan antar data dengan menggunakan Kardinalitas Relasi. Kardinalitas relasi menunjukkan jumlah maksimum tupel yang dapat berelasi dengan entitas pada entitas yang lain [7].

Penelitian ini dilakukan menggunakan metode waterfall. Metode waterfall merupakan model pengembangan sistem informasi yang sistematik dan sekuensial pada perangkat lunak [8]. Langkah penelitian dapat dilihat pada Gambar 1. 


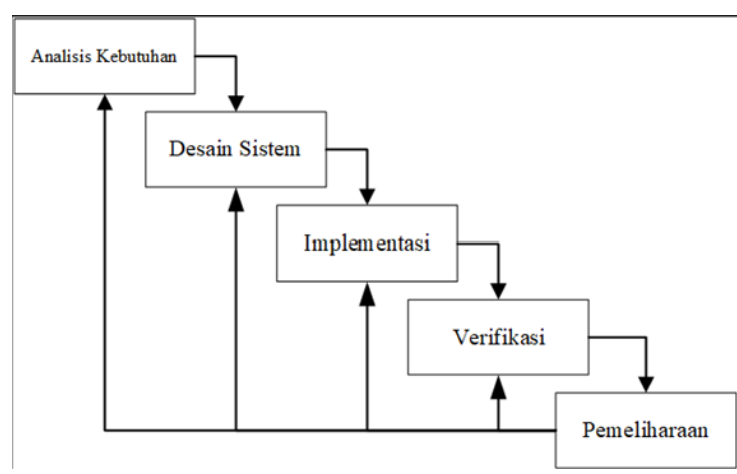

Gambar 1. Langkah Penelitian

Adapun penjelasan dari langkah-langkah penelitian pada gambar 1 adalah sebagai berikut:

\section{A. Analisa Kebutuhan}

Analisa kebutuhan dilakukan dengan melakukan analisis terhadap proses pengajuan tugas akhir yang sedang berjalan di program studi Teknik Sipil Fakultas Teknik Universitas Tanjungpura. Sistem yang sedang berjalan pada proses pengajuan skripsi oleh mahasiswa masih dilakukan secara manual. Proses pengajuan dimulai dari proses periksa persyaratan mahasiswa dalam pengajuan Tugas Akhir.

Berdasarkan analisis sistem yang sedang berjalan, maka diperlukan sistem yang dapat mengelola proses pengajuan mahasiswa dan memberikan data statistik dari pengajuan tugas akhir mahasiswa. Fungsi yang diperlukan pada sistem adalah sistem dapat melakukan aktivitas login untuk mengakses fitur-fitur yang ada pada sistem, sistem dapat melakukan verifikasi nilai mahasiswa sebagai prasyarat pengajuan tugas akhir dari database SIAKAD melalui web service yang disediakan, sistem dapat melakukan input data Kartu Selesai Tugas dan Kartu Selesai Praktikum mahasiswa sebagai syarat untuk melakukan pengajuan tugas akhir, sistem dapat memonitoring kegiatan tugas akhir mahasiswa dengan input data konsultasi dengan dosen pembimbing tugas akhir yang dilakukan oleh mahasiswa secara rutin, dan sistem menampilkan grafik data tugas akhir berdasarkan Kelompok Keahlian.

\section{B. Desain Sistem}

\section{1) Flowchart Sistem}

Flowchart menggambarkan tahapan proses suatu sistem, program flowchart meggambarkan urutan-urutan instruksi dari suatu program komputer, oleh karena itu flowchart yang dihasilkan dapat bervariasi antara suatu program dengan yang lainnya [9].

Pada saat memulai aplikasi, pengguna harus melakukan login terlebih dahulu. Terdapat tiga hak akses, yaitu mahasiswa, admin prodi, dan kepala prodi. Bila pengguna masuk sebagai mahasiswa maka pengguna akan diarahkan ke halaman utama mahasiswa, terdapat halaman pengajuan tugas akhir, halaman upload KST dan KSP, halaman rekapan nilai dari SIAKAD (Sistem Informasi Akademik), halaman upload berita acara seminar proposal skripsi dan sidang tugas akhir, halaman upload rutin proses bimbingan, dan halaman cetak formulir yang diperlukan selama proses tugas akhir.
Jika pengguan terdata sebagai admin maka pengguna akan diarahkan ke halaman utama admin prodi, terdapat manajemen usulan tugas akhir mahasiswa, manajemen kelompok keahlian, manajemen dosen, dan grafik tugas akhir mahasiswa.

Pada saat pengguna login sebagai kaprodi maka pengguna akan diarahkan ke halaman utama kaprodi. Terdapat grafik tugas akhir mahasiswa serta laporan tugas akhir mahasiswa yang sedang berjalan maupun yang telah selesai dilakukan. Flowchart sistem dapat dilihat pada Gambar 2.

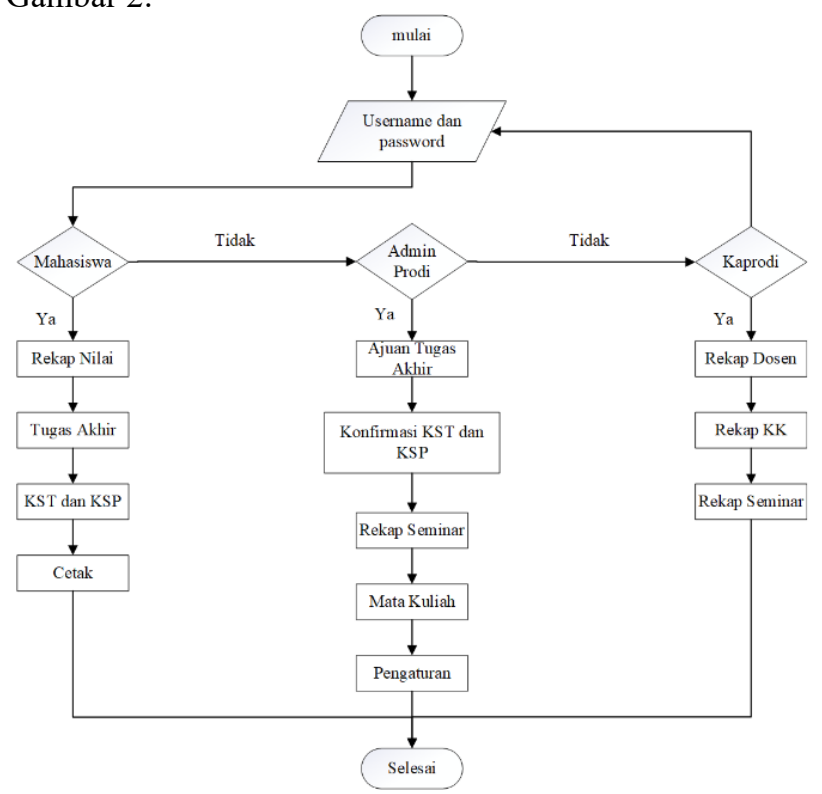

Gambar 2. Flowchart Sistem

\section{2) Diagram Konteks}

Diagram konteks adalah diagram yang memberikan gambaran umum terhadap kegiatan yang berlangsung dalam sistem [10]. Pada diagram konteks sistem informasi dan monitoring tugas akhir yang dibangun terdapat tiga entitas yaitu mahasiswa, operator, dan kaprodi. Diagram konteks dapat dilihat pada Gambar 3 berikut.

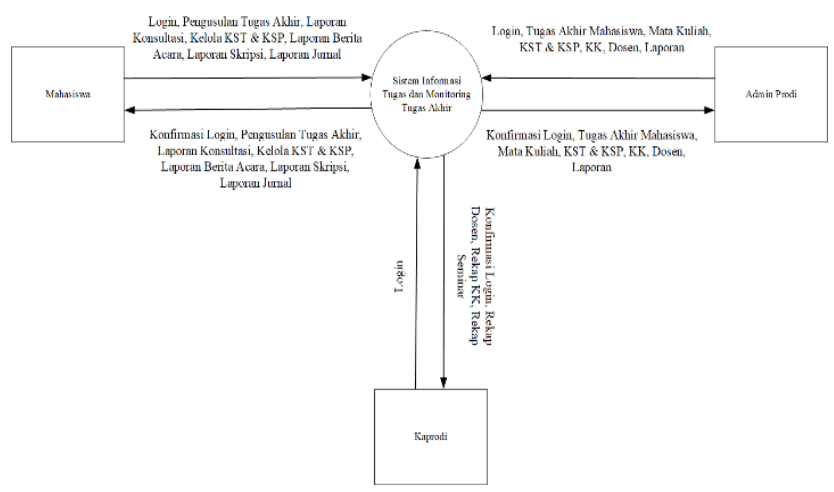

Gambar 3. Diagram Konteks

\section{3) Diagram Overview}

Diagram overview adalah diagram yang menjelaskan urutan-urutan proses yang terjadi pada diagram konteks [11]. Diagram overview sistem dapat dilihat pada Gambar 
4. Berikut penjelasan mengenai diagram overview sistem yang sedang dirancang:

a. Proses 1.0 Login adalah proses autentikasi untuk mengakses aplikasi.

b. Proses 2.0 manajemen usulan adalah proses pengajuan usulan oleh mahasiswa, pengolahan data dosen pembimbing dan penguji tugas akhir, pengolahan putusan, pengolahan kelompok keahlian tugas akhir dan proses validasi usulan oleh operator akademik.

c. Proses 3.0 manajemen KST dan KSP adalah proses pengelolaan Kartu Selesai Tugas dan Kartu Selesai Praktikum oleh mahasiswa dan proses validasi KST dan KSP yang telah di-upload oleh mahasiswa.

d. Proses 4.0 laporan bimbingan adalah proses pelaporan bimbingan pra-outline dan bimbingan skripsi oleh mahasiswa.

e. Proses 5.0 manajemen berita acara adalah proses pelaporan berita acara seminar outline proposal tugas akhir dan sidang akhir.

f. Proses 6.0 manajemen mata kuliah adalah proses pengelolaan matakuliah tugas dan praktikum oleh operator akademik.

g. Proses 7.0 kelompok keahlian adalah proses pengelolaan kelompok keahlian dan dosen.

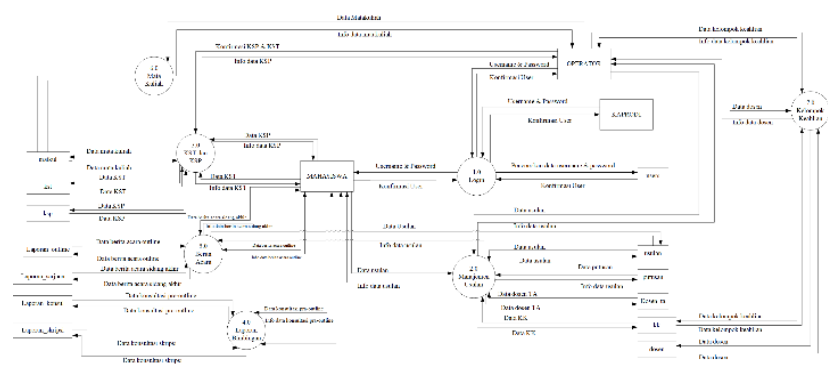

Gambar 4. Diagram Overview

\section{4) Diagram Rinci Sistem}

Diagram rinci menguraikan lebih lanjut mengenai proses dari diagram overview, yang memperlihatkan arus data masuk dan data keluar. Diagram rinci dari setiap proses dapat dilihat pada gambar berikut.

a. Proses 1.0 merupakan proses pengguna memasukkan username dan password pada form login untuk mengakses sistem informasi dan monitorin tugas akhir.

b. Proses 2.0 yaitu proses manajemen usulan. Terdapat 1 proses pada proses 2.1 seperti pada Gambar 5, yaitu Proses 2.1 Manajemen Usulan. Data yang diolah pada manajemen usulan adalah id usulan, id mahasiswa, judul, id kelompok keahlian, id periode, abstrak, draf, data pembinging dan penguji, dan nilai TOEFL.

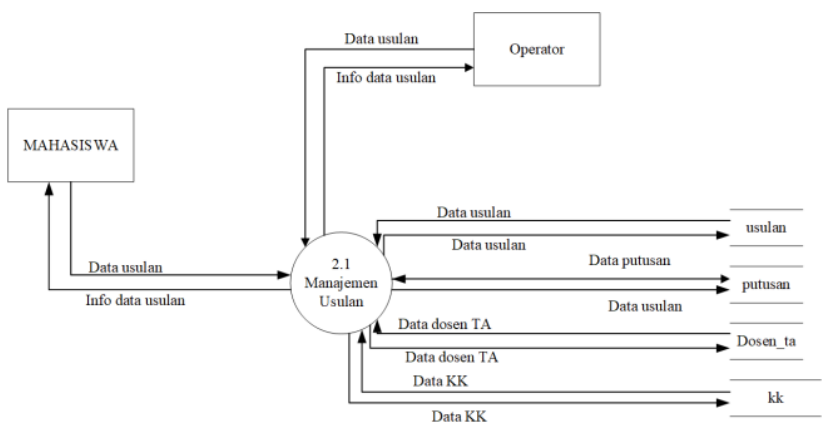

Gambar 5. Diagram Rinci 2.0

c. Proses 3.0 yaitu proses manajemen KST (Kartu Selesai Tugas) dan KSP (Kartu Selesai Praktikum). Proses 3.0 dibagi menjadi 2 proses seperti pada Gambar 6, yaitu Proses 3.1 yaitu Manajemen KSP yang merupakan proses upload Kartu Selesai Praktikum oleh mahasiswa dan validasi oleh operator. Sedangkan Proses 3.2 yaitu Manajemen KST merupakan proses upload Kartu Selesai Tugas oleh mahasiswa dan validasi oleh operator.

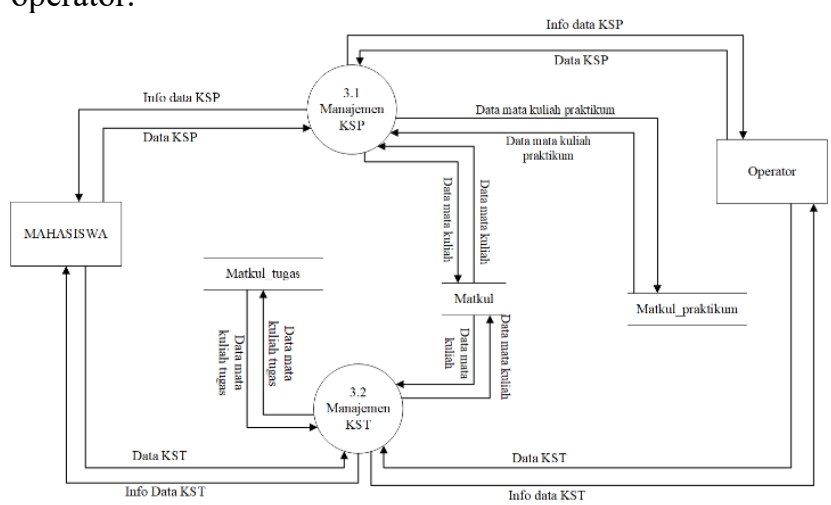

Gambar 6. Diagram Rinci 3.0

d. Proses 4.0 yaitu proses manajemen laporan bimbingan. Proses ini dibagi menjadi dua proses seperti pada Gambar 7, yaitu Proses 4.1 merupakan proses manajemen laporan bimbingan pra-outline oleh mahasiswa dan Proses 4.2 merupakan proses manajemen laporan bimbingan skripsi oleh mahasiswa.

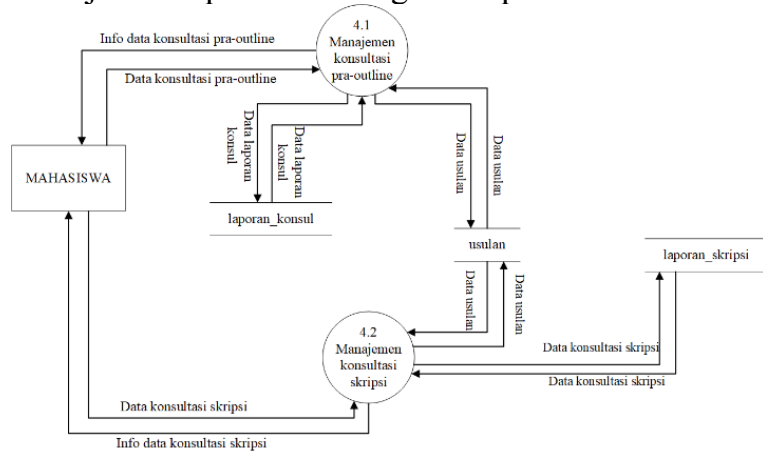

Gambar 7. Diagram Rinci 4.0

e. Proses 5.0 yaitu proses manajemen berita acara. Proses 5.0 dibagi menjadi dua proses seperti pada Gambar 8, yaitu Proses 5.1 yang merupakan proses manajemen berita acara seminar outline oleh mahasiswa, dan Proses 
5.2 yang merupakan proses manajemen berita acara sidang akhir oleh mahasiswa.

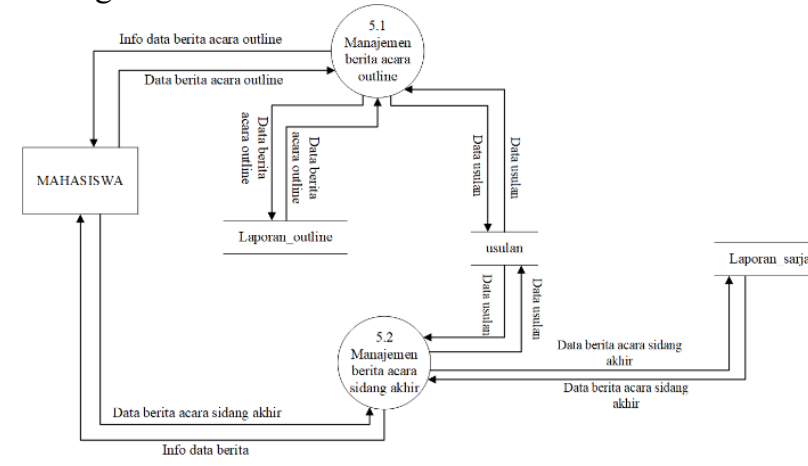

Gambar 8. Diagram Rinci 5.0

f. Proses 6.0 yaitu proses manajemen mata kuliah oleh operator akademik. Proses 6.0 dapat dilihat pada Gambar 9.

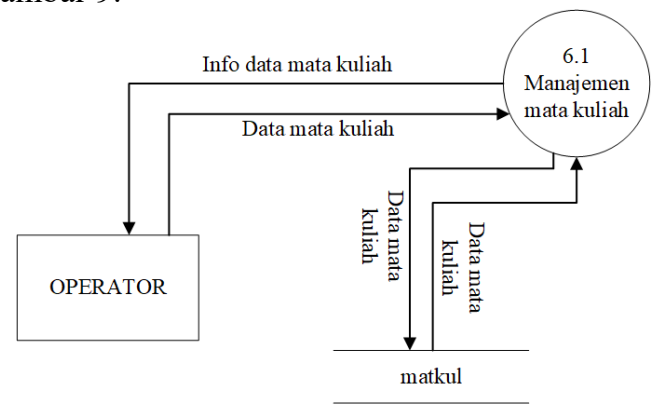

Gambar 9. Diagram Rinci 6.0

g. Proses 7.0 yaitu manajemen kelompok keahlian oleh operator akademik. Proses 7.0 dibagi menjadi dua proses seperti pada Gambar 10 yaitu Proses 7.1 merupakan manajemen kelompok keahlian, dan Proses 7.2 yang merupakan proses manajemen dosen.

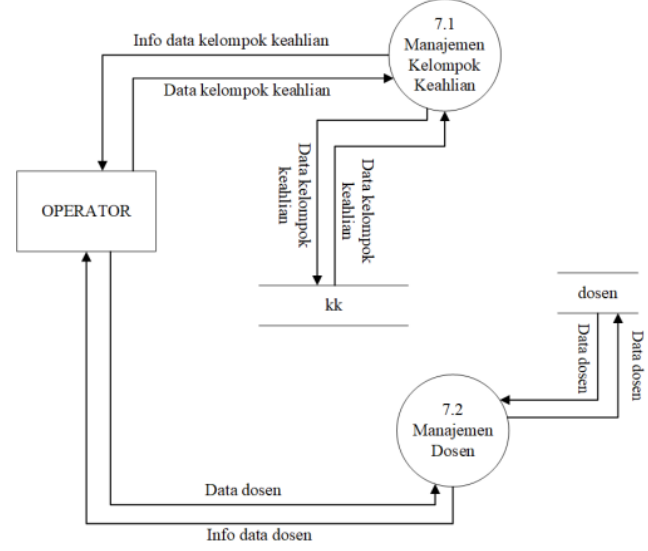

Gambar 10. Diagram Rinci 7.0

\section{5) Entity Relationship Diagram (ERD)}

Berikut tampilan perancangan Entity Relation Diagram pada sistem dapat dilihat pada Gambar 11. Relasi-relasi dan konektivitas yang terjadi pada entitas-entitas yang ada adalah sebagai berikut.

a. Kelompok Keahlian (1) memiliki User (m)

b. Fakultas (1) memiliki Prodi (m)

c. Prodi (1) memiliki Program (m)

d. Usulan (1) memiliki Skripsi Fisik (m) e. Usulan (1) memiliki Putusan (1)

f. Usulan (1) memiliki Dosen TA (m)

g. Mata Kuliah (1) memiliki KSP (m)

h. Mata Kuliah (1) memiliki KST (m)

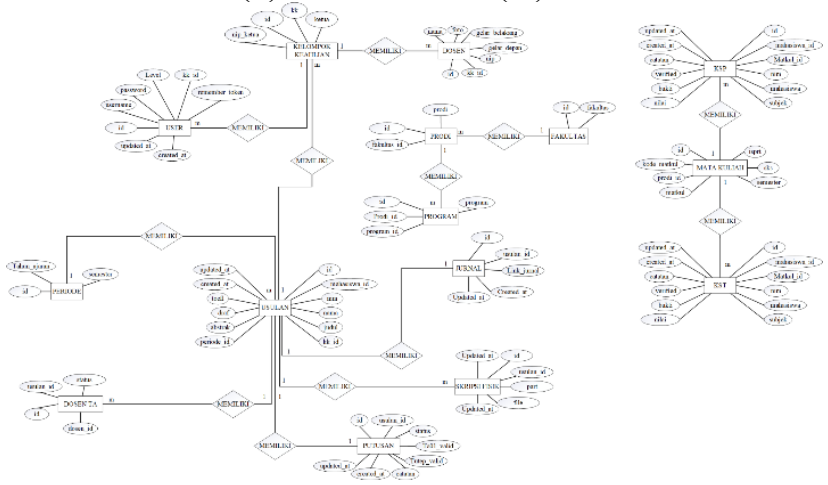

Gambar 11. Entity Relationship Diagram

\section{6) Perancangan Arsitektur Sistem}

Perancangan arsitektur sistem dapat dilihat pada Gambar 12. cara kerja sistem yang akan dibangun yaitu perangkat pengguna melakukan akses ke sistem informasi tugas akhir melalui jaringan internet. Server berfungsi sebagai tempat menyimpan aplikasi dan basis data. Web service SIAKAD berfungsi sebagai cek login mahasiswa dan cek nilai sebagai prasyarat mengusulkan tugas akhir oleh mahasiswa.

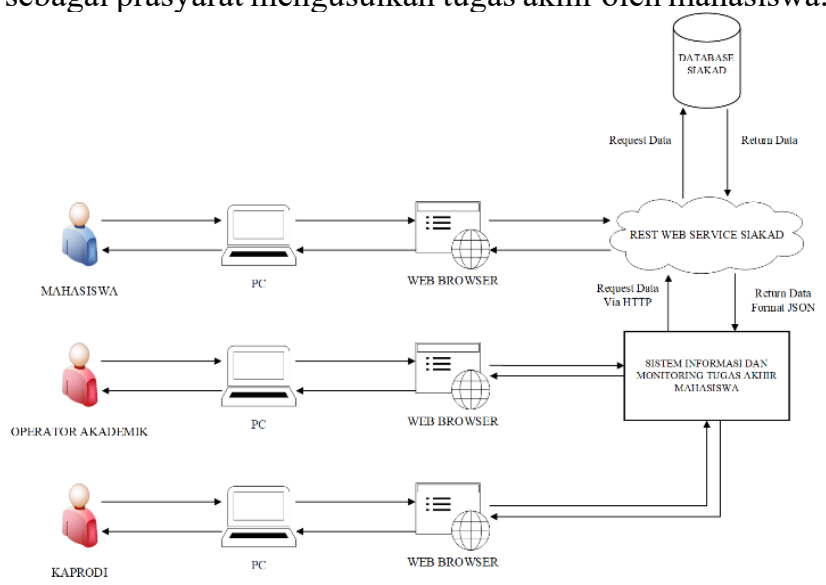

Gambar 12. Perancangan Arsitektur Sistem

\section{7) Perancangan Antar Muka}

Antarmuka sistem dirancang dalam bentuk form-form yang memiliki fungsi tertentu sesuai dengan proses yang ada [12]. Perancangan antar muka sistem dibagi menjadi tiga sesuai dengan entitas yang ada, yaitu struktur antarmuka sistem bagian mahasiswa seperti pada Gambar 13, struktur antarmuka sistem bagian operator akademik dapat dilihat pada Gambar 14, dan Struktur antarmuka sistem bagian kaprodi seperti pada Gambar 15. 


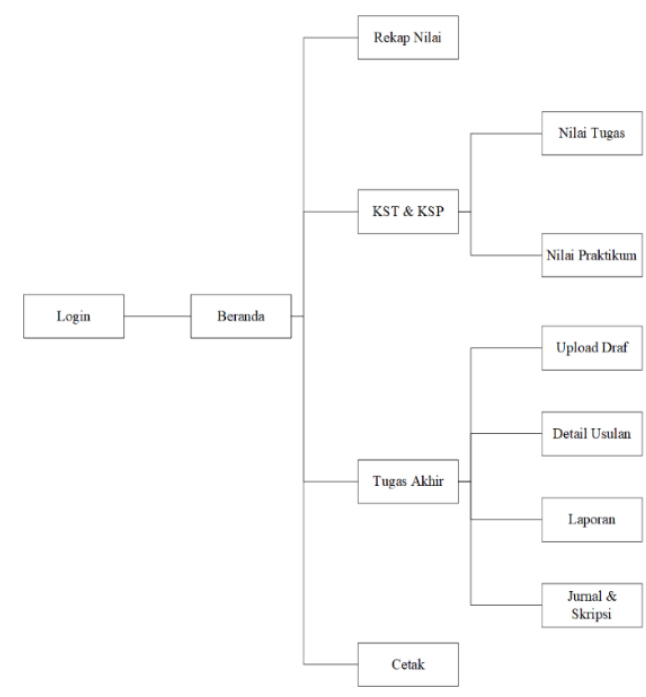

Gambar 13. Struktur Antar Muka Sistem Bagian Mahasiswa

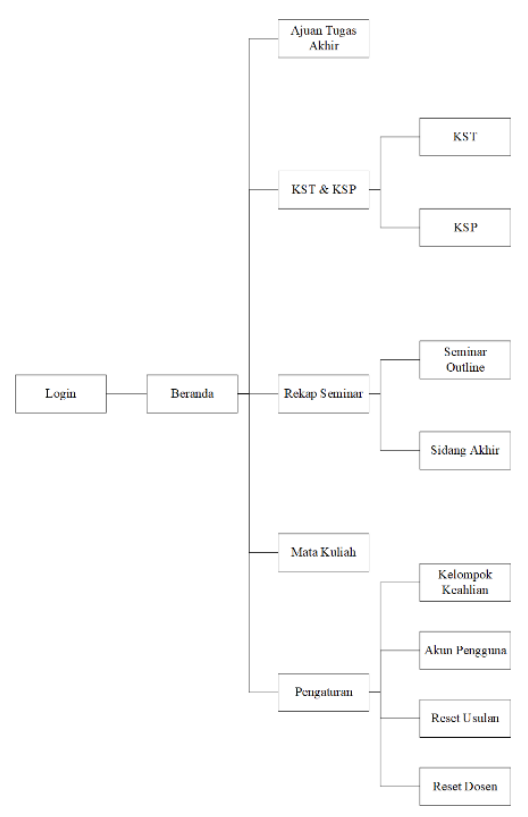

Gambar 14. Struktur Antar Muka Sistem Bagian Operator Akademik

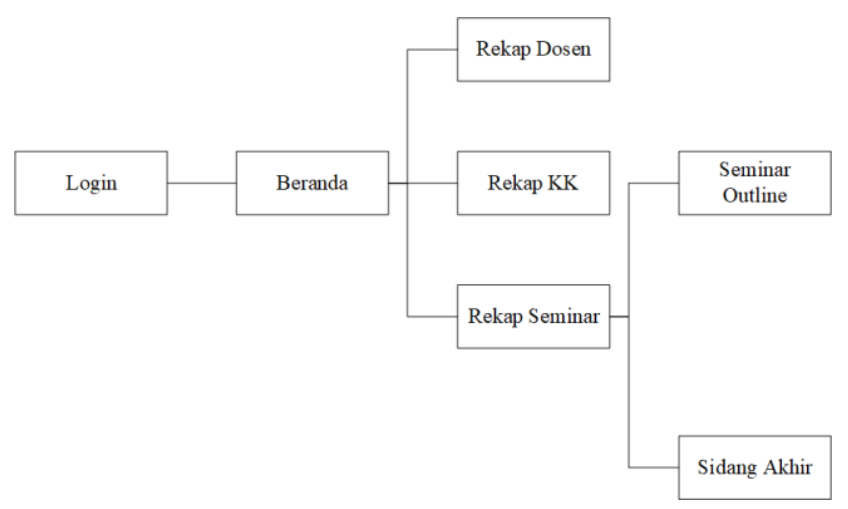

Gambar 15. Struktur Antar Muka Sistem Bagian Kaprodi

\section{Implementasi}

Aplikasi yang akan dibuat akan diimplementasikan pada program studi Teknik Sipil Fakultas Teknik Universitas
Tanjungpura Pontianak. Aplikasi memiliki tiga kriteria pengguna, yaitu mahasiswa, operator akademik, dan kepala program studi. Pengguna dapat mengakses beberapa halaman dari sistem informasi yang akan dibuat, untuk mahasiswa dapat mengakses menu rekap nilai, KST dan KSP, Tugas Akhir, dan Cetak. Untuk operator akademik dapat mengakses menu ajuan tugas akhir mahasiswa, KST dan KSP, rekap seminar, kelola matakuliah, dan pengatuaran. Untuk kepala prodi dapat mengakses menu rekap dosen, rekap kelompok keahlian, dan rekap seminar.

\section{Verifikasi (Pengujian)}

Pengujian sistem merupakan proses untuk mengetahui kelayakan dari sebuah sistem informasi yang telah dibuat. Pada penelitian ini, pengujian dilakukan menggunakan dua metode, yaitu pengujian Black-box dan UAT (User Acceptance Test).

\section{1) Pengujian Black-box}

Metode pengujian black box merupakan pengujian yang dipilih berdasarkan spesifikasi masalah tanpa memperhatikan detail internal dari program, pengujian dilakukan untuk memeriksa apakah program dapat berjalan dengan benar [13].

\section{2) Pengujian UAT (User Acceptance Test)}

User Acceptance Test (UAT) merupakan pengujian yang dilakukan oleh end-user, pihak yang langsung berinteraksi dengan sistem dan dilakukan verifikasi apakah fungsi yang ada telah berjalan sesuai dengan kebutuhan [14].

Tahap pengujian UAT adalah tahap terakhir dari suatu pengembangan perangkat lunak sebelum diserahkan dan digunakan secara luas. Cara untuk mendapatkan suatu data penilaian sebagai bukti yang nyata yang dilakukan end-user salah satunya adalah menggunakan kuesioner.

Kuesioner atau angket merupakan teknik pengumpulan data yang dilakukan dengan cara memberi seperangkat pertanyaan atau pernyataan tertulis kepada responden untuk dijawab guna mendapatkan data atau informasi [15]. Kuesioner diberikan kepada responden (end-user), untuk menentukan penilaian dari tanggapan responden terhadap aplikasi yang dibangun, dapat dilakukan dengan pengukuran skala Guttman yang hanya menggunakan dua interval, diantaranya yaitu "ya atau tidak"; "benar atau salah"; "setuju atau tidak setuju". penggunaan skala Guttman dilakukan bila ingin mendapatkan jawaban yang tegas terhadap suatu permasalahan yang ditanyakan. Penilaian dengan nilai minimal adalah 0 (nol). Misalnya untuk jawaban "ya" diberi skor 1 dan jawaban "tidak" diberi skor 0

\section{3) Kajian Terkait}

Penelitian dengan judul "Perancangan dan Pembuatan Aplikasi Manajemen Publikasi Ilmiah Berbasis Online pada Jurnal SISFO”. Penelitian ini bertujuan untuk membuat aplikasi untuk mengelola jurnal SISFO yang diterbitkan tahunan. Perancangan aplikasi dalam penelitian ini dibangun dengan metode Unified Software Development Process dan perancangan aplikasi menggunakan Unified Modeling Languague (UML) [16]. 
Penelitian dengan judul "Sistem Informasi Kerja Praktek dan Tugas Akhir Program Studi Sistem Komputer" yang dilakukan oleh K. Kusumaningrum bertujuan untuk membuat system informasi kerja praktek di prodi Sistem Komputer UNDIP. DFD digunakan untuk menggambarkan diagram alir sistem dalam penelitian ini [17].

Penelitian dengan judul "Perancangan Sistem Informasi Manajemen Tugas Akhir Berbasis Web Jurusan Teknik Sipil Fakultas Teknik Universitas Tanjungpura" berhasil melakukan perancangan sistem informasi tugas akhir di jurusan teknik sipil untuk memudahkan proses administrasi tugas akhir dan melihat rangkuman basis data tugas akhir di jurusan teknik sipil. Pengujian yang dilakukan menggunakan metode UAT dengan pada 30 pengguna yang sistem informasi yang dirancang [18].

\section{HASIL DAN PEMBAHASAN}

\section{A. Hasil Perancangan}

\section{1) Antar Muka Mahasiswa}

Pada antar muka halaman mahasiswa terdapat lima menu utama yang dapat diakses yaitu menu beranda mahasiswa, menu rekap nilai, menu praktikum dan tugas, menu tugas akhir dan menu cetak. Tampilan Beranda Mahasiswa dapat dilihat seperti pada Gambar 16.

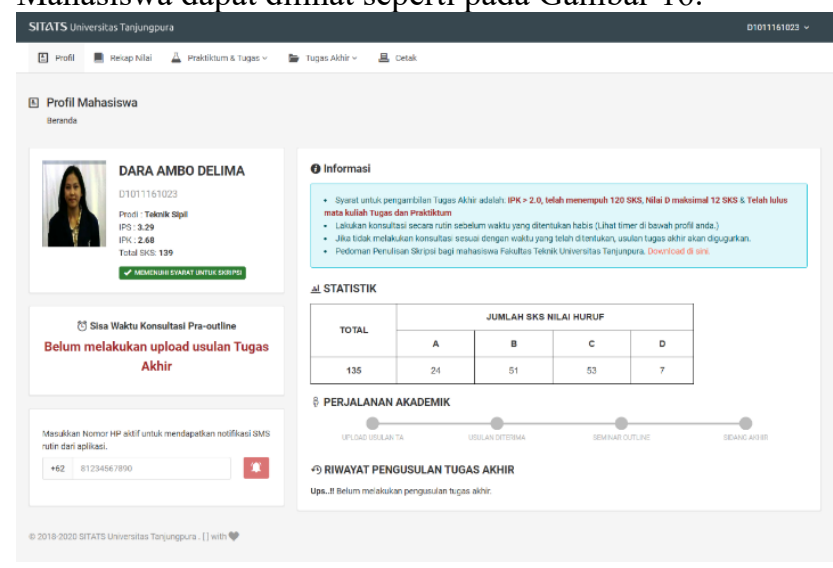

Gambar 16. Tampilan Beranda Mahasiswa

\section{2) Antar Muka Operator Akademik}

Pada antarmuka halaman operator akademik terdapat menu enam menu utama yang dapat diakses yaitu menu beranda, ajuan tugas akhir mahasiswa, KST dan KSP mahasiswa, rekap seminar, kelola mata kuliah, dan menu pengaturan. Tampilan beranda operator akademik dapat dilihat pada Gambar 17.

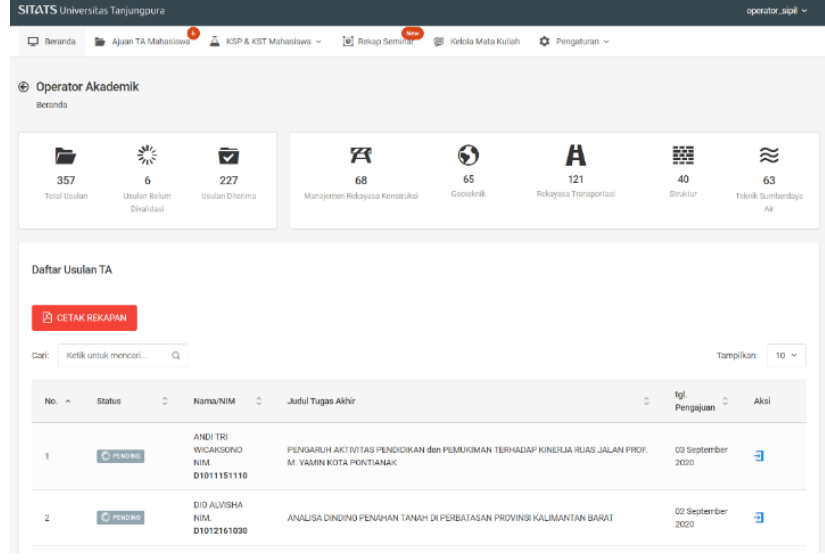

Gambar 17. Tampilan Beranda Operator Akademik

\section{3) Antar Muka Ketua Program Studi}

Pada antarmuka ketua program studi terdapat empat menu utama yang dapat diakses yaitu menu daftar judul, rekap dosen, rekap kelompok keahlian, dan rekap seminar. Tampilan halaman rekap kelompok keahlian pada antarmuka kaprodi dapat dilihat pada Gambar 18.

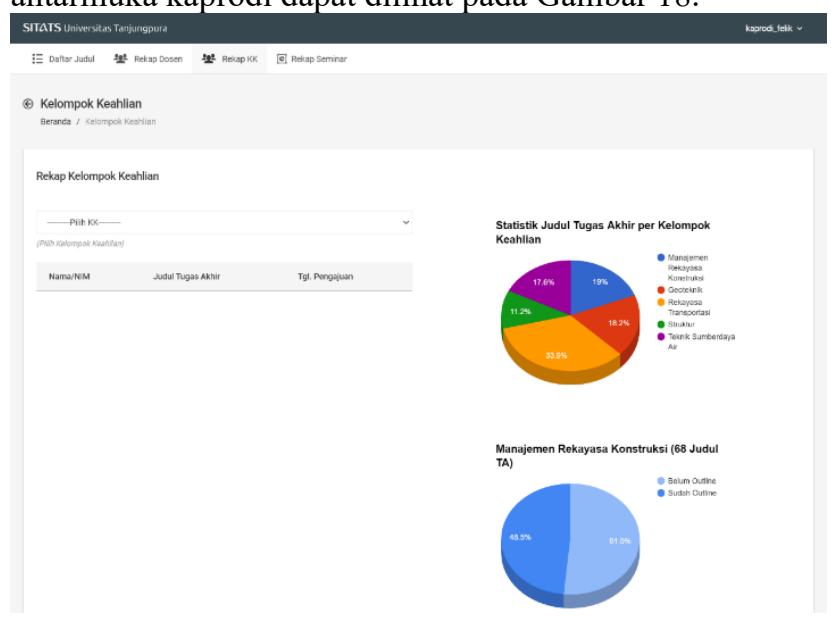

Gambar 18. Tampilan Halaman Rekap Kelompok Keahlian

\section{B. Pengujian Blackbox}

Pengujian blackbox dilakukan dengan teknik sample testing. Sample testing melibatkan beberapa nilai yang terpilih, mengintegrasikan nilai pada kasus uji dan nilainilai yang terpilih mungkin dipilih dengan urutan tertentu atau interval tertentu. Yang akan diuji dengan pengujian blackbox adalah verifikasi nilai mahasiswa oleh sistem, pengujian KST dan KSP sebagai prasyarat pengajuan tugas akhir, input bukti konsultasi pra-outline, input berita acara seminar proposal tugas akhir, input bukti konsultasi tugas akhir, dan input berita acara sidang akhir.

Pengujian blackbox pada sistem informasi dan monitoring tugas akhir dapat dilihat pada tabel-tabel berikut.

Tabel 1 Pengujian Blackbox Pada Verifikasi Nilai Mahasiswa

\begin{tabular}{|c|cr|l|}
\hline Uji Skenario & \multicolumn{2}{|c|}{$\begin{array}{c}\text { Hasil yang } \\
\text { diharapkan }\end{array}$} & Keterangan \\
\hline $\begin{array}{l}\text { Mahasiswa dengan } \\
\text { IPK }<2.0, \text { total SKS }\end{array}$ & $\begin{array}{rrr}\text { Tidak } & \text { memenuhi } \\
\text { syarat } & \text { untuk }\end{array}$ & Berhasil \\
\hline
\end{tabular}




\begin{tabular}{|l|l|l|}
\hline $\begin{array}{l}<120, \text { dan nilai } \\
\text { huruf } \mathrm{D}>12 \text { SKS }\end{array}$ & $\begin{array}{l}\text { mengajukan usulan } \\
\text { tugas akhir }\end{array}$ & \\
\hline $\begin{array}{l}\text { Mahasiswa dengan } \\
\text { IPK } \geq 2.0, \text { SKS } \geq\end{array}$ & $\begin{array}{l}\text { Memenuhi syarat } \\
\text { untuk mengajukan }\end{array}$ & Berhasil \\
120, dan nilai huruf & $\begin{array}{l}\text { usulan tugas akhir } \\
\mathrm{D} \leq 12 \text { SKS }\end{array}$ & \\
\hline
\end{tabular}

Tabel 2 Pengujian Blackbox Pada KST Dan KSP

\begin{tabular}{|c|c|c|}
\hline Uji Skenario & $\begin{array}{c}\text { Hasil yang } \\
\text { diharapkan }\end{array}$ & Keterangan \\
\hline $\begin{array}{lr}\text { Kartu } & \text { Selesai } \\
\text { Praktikum } & \text { tidak } \\
\text { lengkap } & \\
\end{array}$ & $\begin{array}{ll}\text { Form usulan } & \text { tugas } \\
\text { akhir } & \text { tidak } \\
\text { ditampilkan } & \\
\end{array}$ & Berhasil \\
\hline $\begin{array}{lr}\text { Kartu } & \text { Selesai } \\
\text { Tugas } & \text { tidak } \\
\text { lengkap } & \\
\end{array}$ & $\begin{array}{lr}\begin{array}{l}\text { Form usulan } \\
\text { akhir } \\
\text { ditampilkan }\end{array} & \text { tidak } \\
\end{array}$ & Berhasil \\
\hline $\begin{array}{lr}\text { Kartu } & \text { Selesai } \\
\text { Tugas lengkap dan } \\
\text { Kartu } & \text { Selesai } \\
\text { Praktikum } & \text { tidak } \\
\text { lengkap } & \\
\end{array}$ & $\begin{array}{ll}\text { Form usulan } & \text { tugas } \\
\text { akhir } & \text { tidak } \\
\text { ditampilkan } & \end{array}$ & Berhasil \\
\hline $\begin{array}{lr}\text { Kartu } & \text { Selesai } \\
\text { Tugas } & \text { tidak } \\
\text { lengkap } & \text { dan Kartu } \\
\text { Selesai } & \text { Praktikum } \\
\text { lengkap } & \\
\end{array}$ & $\begin{array}{ll}\text { Form usulan tugas } \\
\text { akhir } & \text { tidak } \\
\text { ditampilkan } & \end{array}$ & Berhasil \\
\hline $\begin{array}{lr}\text { Kartu } & \text { Selesai } \\
\text { Tugas } & \text { Lengkap } \\
\text { dan Kartu Selesai } & \text { Sraktikum lengkap } \\
\text { Praktikn }\end{array}$ & $\begin{array}{l}\text { Form upload usulan } \\
\text { tugas } \\
\text { ditampilkan }\end{array}$ & Berhasil \\
\hline
\end{tabular}

Tabel 3 Pengujian Blackbox Pada Proses InPut Bukti KONSULTASI PRAOUTLINE

\begin{tabular}{|l|l|l|}
\hline \multicolumn{1}{|c|}{ Uji Skenario } & \multicolumn{1}{|c|}{$\begin{array}{c}\text { Hasil yang } \\
\text { diharapkan }\end{array}$} & Keterangan \\
\hline $\begin{array}{l}\text { Usulan tugas } \\
\text { akhir kosong }\end{array}$ & $\begin{array}{l}\text { Tombol upload bukti } \\
\text { konsultasi tidak } \\
\text { ditampilkan }\end{array}$ & Berhasil \\
\hline $\begin{array}{l}\text { Usulan tugas } \\
\text { akhir belum } \\
\text { diverifikasi }\end{array}$ & $\begin{array}{l}\text { Tombol upload bukti } \\
\text { konsultasi tidak } \\
\text { ditampilkan }\end{array}$ & Berhasil \\
\hline $\begin{array}{l}\text { Usulan tugas } \\
\text { akhir diterima }\end{array}$ & $\begin{array}{l}\text { Tombol upload bukti } \\
\text { konsultasi ditampilkan }\end{array}$ & Berhasil \\
\hline
\end{tabular}

Tabel 4 Pengujian Blackbox pada Proses InPut Berita ACara SEMINAR PROPOSAL

\begin{tabular}{|c|c|c|}
\hline Uji Skenario & $\begin{array}{c}\text { Hasil yang } \\
\text { diharapkan }\end{array}$ & Keterangan \\
\hline $\begin{array}{lr}\text { Bukti } & \text { konsultasi } \\
\text { pra } & \text { seminar } \\
\text { outline } & \text { kurang } \\
\text { dari 3 } & \\
\end{array}$ & $\begin{array}{l}\text { Tombol upload berita } \\
\text { acara seminar outline } \\
\text { tidak ditampilkan }\end{array}$ & Berhasil \\
\hline $\begin{array}{l}\text { Bukti konsultasi } \\
\text { pra seminar } \\
\text { outline lebih dari } \\
\text { atau sama dengan } \\
3\end{array}$ & $\begin{array}{l}\text { Tombol upload berita } \\
\text { acara seminar outline } \\
\text { ditampilkan }\end{array}$ & Berhasil \\
\hline
\end{tabular}

TABel 5 PENGUJian BlackboX PADA Proses INPUT BUKTI KONSUltasi PASCA SEMINAR OUTLINE

\begin{tabular}{|c|c|c|}
\hline Uji Skenario & $\begin{array}{c}\text { Hasil yang } \\
\text { diharapkan }\end{array}$ & Keterangan \\
\hline
\end{tabular}

\begin{tabular}{|l|l|l|}
\hline $\begin{array}{l}\text { Berita Acara } \\
\text { seminar outline } \\
\text { belum di-input }\end{array}$ & $\begin{array}{l}\text { Tombol upload bukti } \\
\text { konsultasi pasca } \\
\text { seminar outline tidak } \\
\text { ditampilkan }\end{array}$ & Berhasil \\
\hline $\begin{array}{l}\text { Berita Acara } \\
\text { seminar outline } \\
\text { proposal telah di- } \\
\text { input }\end{array}$ & $\begin{array}{l}\text { Tombol upload bukti } \\
\text { keminar pasca } \\
\text { semar outline } \\
\text { ditampilkan }\end{array}$ & Berhasil \\
\hline
\end{tabular}

Tabel 6 Pengujian Blackbox pada Proses InPut Berita Acara SIDANG AKHIR

\begin{tabular}{|c|c|c|}
\hline Uji Skenario & $\begin{array}{c}\text { Hasil yang } \\
\text { diharapkan }\end{array}$ & Keterangan \\
\hline $\begin{array}{lr}\text { Bukti } & \text { konsultasi } \\
\text { pasca } & \text { seminar } \\
\text { outline } & \text { kurang } \\
\text { dari 10 } & \end{array}$ & $\begin{array}{l}\text { Tombol upload } \\
\text { bukti berita acara } \\
\text { sidang akhir tidak } \\
\text { ditampilkan }\end{array}$ & Berhasil \\
\hline $\begin{array}{l}\text { Bukti konsultasi } \\
\text { pasca seminar } \\
\text { outline lebih dari } \\
\text { atau sama dengan } \\
10\end{array}$ & $\begin{array}{ll}\text { Tombol upload } \\
\text { bukti berita } & \text { acara } \\
\text { sidang } & \text { akhir } \\
\text { ditampilkan } & \end{array}$ & Berhasil \\
\hline
\end{tabular}

\section{Pengujian Kuesioner}

Hasil pengujian kuesioner dari 42 responden mahasiswa dapat dilihat pada Tabel 7.

\begin{tabular}{|c|c|c|c|c|c|c|c|}
\hline \multirow{2}{*}{$\begin{array}{c}\text { No } \\
\text {. }\end{array}$} & \multirow{2}{*}{$\begin{array}{c}\text { Pernyataa } \\
\text { n }\end{array}$} & \multicolumn{5}{|c|}{ Respon } & \multirow{2}{*}{$\begin{array}{c}\text { Tot } \\
\text { al }\end{array}$} \\
\hline & & sts & ts & cs & $\mathbf{S}$ & SS & \\
\hline 1 & $\begin{array}{l}\text { Sistem } \\
\text { informasi } \\
\text { tugas akhir } \\
\text { dapat } \\
\text { diakses } \\
\text { dengan } \\
\text { mudah. }\end{array}$ & 0 & 4 & 15 & 20 & 3 & 42 \\
\hline 2 & $\begin{array}{l}\text { Antar muka } \\
\text { sistem } \\
\text { informasi } \\
\text { tugas akhir } \\
\text { sudah baik } \\
\text { dan mudah } \\
\text { digunakan }\end{array}$ & 0 & 10 & 16 & 13 & 3 & 42 \\
\hline 3 & $\begin{array}{l}\text { Sistem } \\
\text { informasi } \\
\text { tugas akhir } \\
\text { berjalan } \\
\text { baik pada } \\
\text { perangkat } \\
\text { komputer } \\
\text { desktop }\end{array}$ & 1 & 1 & 21 & 17 & 2 & 42 \\
\hline 4 & $\begin{array}{l}\text { Sistem } \\
\text { informasi } \\
\text { tugas akhir } \\
\text { berjalan } \\
\text { baik pada } \\
\text { perangkat } \\
\text { mobile } \\
\end{array}$ & 3 & 5 & 18 & 16 & 0 & 42 \\
\hline 5 & $\begin{array}{l}\text { Fitur-fitur } \\
\text { yang } \\
\text { disediakan } \\
\text { berjalan } \\
\text { dengan baik }\end{array}$ & 0 & 3 & 22 & 16 & 1 & 42 \\
\hline
\end{tabular}




\begin{tabular}{|c|c|c|c|c|c|c|c|}
\hline 6 & $\begin{array}{l}\text { Sistem } \\
\text { informasi } \\
\text { tugas akhir } \\
\text { mudah } \\
\text { digunakan }\end{array}$ & 0 & 4 & 18 & 18 & 2 & 42 \\
\hline 7 & $\begin{array}{l}\text { Sistem } \\
\text { informasi } \\
\text { tugas akhir } \\
\text { secara } \\
\text { efektif } \\
\text { memudahk } \\
\text { an } \\
\text { mahasiswa } \\
\text { dalam } \\
\text { proses } \\
\text { pengajuan } \\
\text { tugas akhir }\end{array}$ & 0 & 4 & 18 & 18 & 2 & 42 \\
\hline 8 & $\begin{array}{l}\text { Sistem } \\
\text { informasi } \\
\text { tugas akhir } \\
\text { mahasiswa } \\
\text { secara } \\
\text { efektif } \\
\text { memonitori } \\
\text { ng proses } \\
\text { tugas akhir } \\
\text { mahasiswa }\end{array}$ & 1 & 4 & 20 & 14 & 3 & 42 \\
\hline 9 & $\begin{array}{l}\text { Sistem } \\
\text { informasi } \\
\text { tugas akhir } \\
\text { membantu } \\
\text { proses } \\
\text { digitalisasi } \\
\text { proses } \\
\text { pengajuan } \\
\text { usulan } \\
\text { tugas akhir } \\
\text { mahasiswa }\end{array}$ & 0 & 3 & 16 & 19 & 4 & 42 \\
\hline 10 & $\begin{array}{l}\text { Sistem } \\
\text { informasi } \\
\text { tugas akhir } \\
\text { membantu } \\
\text { proses } \\
\text { pelaporan } \\
\text { konsultasi } \\
\text { dan berita } \\
\text { acara tugas } \\
\text { akhir } \\
\end{array}$ & 0 & 4 & 20 & 15 & 3 & 42 \\
\hline \multicolumn{2}{|c|}{ Jumlah } & 5 & 42 & 184 & 166 & 23 & 420 \\
\hline \multicolumn{2}{|c|}{ Persentase } & 1,19 & 10 & 43,8 & 39,5 & $\begin{array}{l}5, \\
47\end{array}$ & 100 \\
\hline
\end{tabular}

Persentase aspek rekayasa perangkat lunak dapat dilihat pada Gambar 19.

\section{PERSENTASE ASPEK PERANGKAT LUNAK}

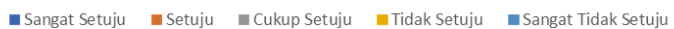

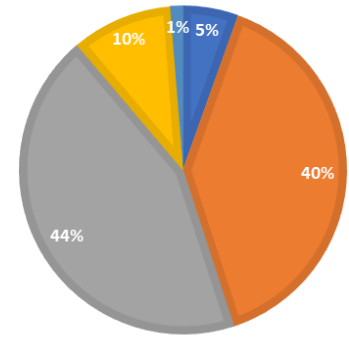

Gambar 19. Persentase Aspek Perangkat Lunak

D. Pengujian UAT (User Acceptance Test)

Hasil pengujian UAT dapat dilihat pada tabel berikut

\begin{tabular}{|c|c|c|c|c|c|c|c|c|c|c|c|}
\hline \multirow[b]{2}{*}{ Responden } & \multicolumn{10}{|c|}{ Nilai } & \multirow[b]{2}{*}{ Total } \\
\hline & 1 & 2 & 3 & 4 & 5 & 6 & 7 & 8 & 9 & 10 & \\
\hline 1 & 5 & 5 & 5 & 4 & 5 & 5 & 5 & 5 & 5 & 5 & 49 \\
\hline 2 & 3 & 4 & 3 & 4 & 4 & 4 & 3 & 3 & 4 & 3 & 35 \\
\hline 3 & 4 & 3 & 3 & 3 & 3 & 3 & 3 & 3 & 4 & 3 & 32 \\
\hline 4 & 4 & 4 & 4 & 4 & 4 & 4 & 4 & 4 & 4 & 4 & 40 \\
\hline 5 & 4 & 3 & 4 & 1 & 4 & 4 & 4 & 4 & 2 & 3 & 33 \\
\hline 6 & 3 & 2 & 4 & 1 & 3 & 4 & 2 & 3 & 4 & 2 & 28 \\
\hline 7 & 3 & 3 & 3 & 3 & 3 & 3 & 3 & 3 & 3 & 3 & 30 \\
\hline 8 & 4 & 4 & 4 & 4 & 4 & 4 & 4 & 5 & 5 & 5 & 43 \\
\hline 9 & 3 & 3 & 4 & 3 & 3 & 3 & 3 & 3 & 4 & 3 & 32 \\
\hline 10 & 4 & 3 & 3 & 3 & 3 & 4 & 4 & 4 & 4 & 4 & 36 \\
\hline 11 & 3 & 3 & 3 & 3 & 3 & 3 & 3 & 3 & 3 & 3 & 30 \\
\hline 12 & 4 & 3 & 5 & 4 & 2 & 3 & 3 & 4 & 4 & 3 & 35 \\
\hline 13 & 5 & 2 & 3 & 3 & 3 & 3 & 3 & 3 & 3 & 3 & 31 \\
\hline 14 & 4 & 4 & 4 & 4 & 4 & 4 & 4 & 4 & 4 & 4 & 40 \\
\hline 15 & 4 & 5 & 3 & 4 & 4 & 4 & 4 & 4 & 4 & 4 & 40 \\
\hline 16 & 2 & 2 & 4 & 3 & 3 & 3 & 3 & 3 & 3 & 3 & 29 \\
\hline 17 & 3 & 3 & 4 & 4 & 3 & 3 & 4 & 4 & 4 & 4 & 36 \\
\hline 18 & 3 & 3 & 3 & 3 & 3 & 3 & 3 & 3 & 3 & 3 & 30 \\
\hline 19 & 4 & 3 & 3 & 3 & 3 & 3 & 3 & 4 & 4 & 3 & 33 \\
\hline 20 & 4 & 4 & 3 & 3 & 4 & 5 & 3 & 3 & 5 & 4 & 38 \\
\hline 21 & 4 & 4 & 3 & 3 & 3 & 3 & 4 & 3 & 4 & 3 & 34 \\
\hline 22 & 4 & 4 & 4 & 4 & 4 & 4 & 4 & 4 & 4 & 4 & 40 \\
\hline 23 & 4 & 4 & 4 & 4 & 4 & 4 & 5 & 5 & 5 & 5 & 44 \\
\hline 24 & 4 & 3 & 3 & 3 & 3 & 3 & 3 & 3 & 3 & 3 & 31 \\
\hline
\end{tabular}




\begin{tabular}{|l|l|l|l|l|l|l|l|l|l|l|l|}
\hline 25 & 3 & 2 & 3 & 2 & 3 & 3 & 3 & 2 & 3 & 3 & 27 \\
\hline 26 & 2 & 2 & 1 & 3 & 2 & 2 & 2 & 2 & 2 & 2 & 20 \\
\hline 27 & 3 & 2 & 3 & 2 & 3 & 3 & 3 & 2 & 3 & 3 & 27 \\
\hline 28 & 4 & 4 & 3 & 3 & 3 & 3 & 3 & 3 & 3 & 4 & 33 \\
\hline 29 & 2 & 2 & 2 & 1 & 2 & 2 & 2 & 1 & 2 & 2 & 18 \\
\hline 30 & 4 & 4 & 4 & 4 & 4 & 4 & 4 & 3 & 4 & 3 & 38 \\
\hline 31 & 3 & 3 & 3 & 3 & 4 & 4 & 4 & 3 & 3 & 4 & 34 \\
\hline 32 & 4 & 4 & 4 & 4 & 4 & 4 & 4 & 4 & 4 & 4 & 40 \\
\hline 33 & 3 & 2 & 3 & 3 & 3 & 3 & 4 & 4 & 3 & 4 & 32 \\
\hline 34 & 4 & 4 & 4 & 4 & 4 & 4 & 4 & 4 & 4 & 4 & 40 \\
\hline 35 & 5 & 2 & 3 & 3 & 4 & 3 & 3 & 3 & 3 & 3 & 32 \\
\hline 36 & 2 & 5 & 4 & 2 & 3 & 2 & 4 & 3 & 4 & 2 & 31 \\
\hline 37 & 3 & 3 & 3 & 3 & 3 & 2 & 2 & 3 & 3 & 3 & 28 \\
\hline 38 & 4 & 3 & 4 & 4 & 4 & 4 & 4 & 2 & 4 & 4 & 37 \\
\hline 39 & 3 & 3 & 3 & 4 & 3 & 4 & 4 & 3 & 3 & 3 & 33 \\
\hline 40 & 3 & 3 & 4 & 2 & 3 & 4 & 3 & 4 & 3 & 4 & 33 \\
\hline 41 & 4 & 4 & 4 & 4 & 4 & 4 & 4 & 4 & 4 & 4 & 40 \\
\hline 42 & 3 & 2 & 3 & 2 & 3 & 3 & 3 & 3 & 3 & 3 & 28 \\
\hline & & & Skor & & & & & 1420 \\
\hline
\end{tabular}

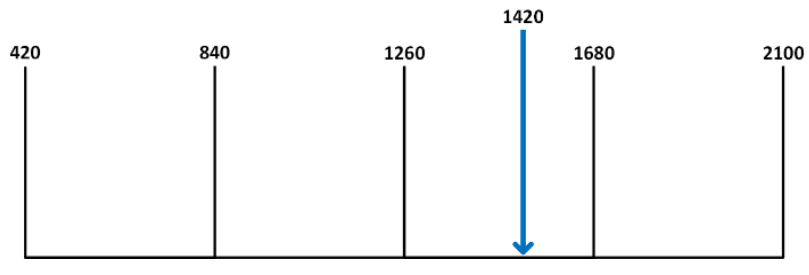

Gambar 20. Skor dalam Skala Likert

Gambar 4.39 menunjukkan bahwa hasil penelitian berada diantara skor 1260 dan 1680 yang berarti, hasil kuesioner menandakan responden menilai aplikasi positif dan dinilai cukup berhasil.

\section{KESIMPULAN}

1. Hasil pengujian Black Box menunjukkan bahwa komponen dan fungsi pada sistem berjalan sesuai dengan yang diharapkan.

2. Berdasarkan hasil pengujian dengan kuesioner yang telah diisi pada Sistem Informasi dan Monitoring Tugas Akhir Mahasiswa di Program Studi Teknik Sipil Fakultas Teknik Universitas Tanjungpura, mahasiswa menanggapi sistem informasi cukup memenuhi tujuan seperti yang diharapkan pada setiap pernyataan dianggap cukup layak untuk digunakan.

3. Hasil pengujian yang diukur dengan metode UAT menunjukkan bahwa responden mahasiswa menilai sistem cukup positif dan berhasil, dapat dikategorikan cukup setuju dengan menghasilkan nilai 1420 dari 10 pertanyaan yang diberikan.

4. Sistem Informasi dan Monitoring Tugas Akhir Mahasiswa di Program Studi Teknik Sipil Universitas Tanjunpura berhasil dibangun sehingga bisa diimplementasikan di Program Studi Teknik Sipil.

5. Sistem informasi dan monitoring tugas akhir berhasil dibangun sehingga dapat digunakan oleh mahasiswa untuk melakukan pengajuan dan monitoring tugas akhir.

\section{DAFTAR PUSTAKA}

[1] Syahdrajat, Tantur. Panduan menulis tugas akhir kedokteran \& kesehatan. Kencana, 2015.

[2] Jogiyanto, Hartono M. Analisis dan Desain (Sistem Informasi Pendekatan Terstruktur Teori dan Praktek Aplikasi Bisnis). Penerbit Andi, 2017.

[3] KADIR, Abdul. Pengenbangan Sistem Informasi. Yoyakarta: Penerbit Andi, 2003.

[4] ROSA, Ariani Sukamto. Rekayasa perangkat lunak terstruktur dan berorientasi objek. 2016.

[5] Kristanto, Andri. Perancangan Sistem Informasi dan Aplikasinya, edisi revisi, Yogyakarta: Gava Media, 2008.

[6] LADJAMUDIN, Al-Bahra Bin. Analisis dan desain sistem informasi. Yogyakarta: Graha Ilmu, 2005, 1: 1-6.

[7] LADJAMUDDIN, Al-Bahra. Konsep Sistem Basis Data dan Implementasinya. Graha Ilmu, Yogyakarta, 2004.

[8] PRESSMAN, Roger S. Rekayasa Perangkat Lunak Pendekatan Praktisi (Buku Satu). Yogyakarta: Andi, 2002.

[9] SUYANTO, Muhammad, et al. Analisis \& desain aplikasi multimedia untuk pemasaran. Penerbit Andi, 2004

[10] YURIDA, Nur Harsi; SUKAMTO, Anggi Srimurdianti; MUHARDI, Hafiz. Aplikasi Virtual Tour pada Ruang Pelayanan RSUD Dr. Soedarso Pontianak. JUSTIN (Jurnal Sistem dan Teknologi Informasi), 2018, 6.2: 96-103. 
[11] RAJA, Hebdro Manik; PUTRA, Arif Bijaksana; IRWANSYAH, Azhar. Rancang Bangun Sistem Informasi Geografis Berbasis Web Fasilitas Pelayanan Kesehatan Di Kota Pontianak. JEPIN (Jurnal Edukasi dan Penelitian Informatika), 2015, 1.2: 64-71.

[12] KRESNA, Deassy Kartika. Sistem Informasi Geografis Penentuan Sebaran Listrik Desa Kabupaten Sintang. JUSTIN (Jurnal Sistem dan Teknologi Informasi), 2013, 1.3: 161-165.

[13] Sukamto, RA, och M Shalahuddin. Rekayasa Perangkat Lunak Terstruktur dan Berorientasi Objek. Bandung: Modula, 2013.

[14] Sugiyono. Metode Penelitian Kuantitatif Kualitatif dan R\&D. Bandung: Alfabeta, 2008.

[15] NEYFA, Bella Chintya; TAMARA, Dony. Perancangan Aplikasi E-Canteen Berbasis Android Dengan Menggunakan Metode Object Oriented Analysis \& Design (OOAD). J. Penelit. Komun. dan Opini Publik, 2016, 20.1: 83-92.

[16] SIMAREMARE, Yosua; PRIBADI, Apol; WIBOWO, Radityo Prasetianto. Perancangan dan Pembuatan Aplikasi Manajemen Publikasi Ilmiah Berbasis Online pada Jurnal SISFO. Jurnal Teknik ITS, 2013, 2.3: A470-A475.

[17] KUSUMANINGRUM, Karlina; ROCHIM, Adian Fatchur; KRIDALUKMANA, Rinta. Sistem Informasi Kerja Praktek dan Tugas Akhir Program Studi Sistem Komputer. Jurnal Teknologi dan Sistem Komputer, 2013, 1.2: 21-27.

[18] WULANSARI, Endah. Perancangan Sistem Informasi Manajemen Tugas Akhir Berbasis Web Jurusan Teknik Sipil Fakultas Teknik Universitas Tanjungpura. Uiversitas Tanjungpura, 2014. 